\title{
American History X, Cinematic Manipulation, and Moral Conversion
}

\author{
Christopher Grau
}

For Volume XXXIV of Midwest Studies in Philosophy: Film \& Emotions

\section{Introduction}

American History $X$ (hereafter $A H X$ ) has been accused by numerous critics of a morally dangerous cinematic seduction: using stylish cinematography, editing, and sound, the film manipulates the viewer through glamorizing an immoral and hate-filled neo-nazi protagonist. In addition, there's the disturbing fact that the film seems to accomplish this manipulation through methods commonly grouped under the category of "fascist aesthetics." More specifically, $A H X$ promotes its neo-nazi hero through the use of several filmic techniques made famous by Nazi propagandist Leni Riefenstahl. Now most critics admit that, in the end, the film claims to denounce racism and attempts to show us the conversion of the protagonist to the path of righteousness, but they complain that nonetheless the film (perhaps unintentionally) ends up implicitly promoting the immoral worldview it rather superficially professes to reject in its final act.

This charge of hypocrisy is connected to another worry: the moral conversion in the film is said to fall flat because the intellectual resources on display to support the character's racism are not counterbalanced by equally explicit (but superior) arguments for the anti-racist position ultimately embraced by the character. In other words, just as the devil is said to get all the good lines in Milton's Paradise Lost, in AHX the racists get all the arguments. This has been taken to be a morally problematic flaw of the film. Critics lament that Derek's conversion seems to result not from relevant logical inferences and valid rational argumentation but from overly simplistic and arguably egoistic insights (e.g., "has anything you've done made your life better?") combined, perhaps, with a hackneyed cliché (in prison, one of his best friends is a black person!)

In this paper I'll attempt to rebut these charges and defend the film as a powerful, and powerfully moral, work of art. ${ }^{1}$ I'll be suggesting that the seductive techniques employed allow for many viewers a degree of sympathy towards the protagonist that is crucial, both for making that character's more horrific actions especially unsettling, and also for making his eventual conversion plausible and ultimately compelling. I'll also argue that the manner

\footnotetext{
${ }^{1}$ In making the case for the moral defensibility of this film I am not blind to the fact that it is no masterpiece: while I consider it a powerful and successful film, various details of the plotting are clichéd, while other aspects of the film (such as the "write a paper on your brother" framing device and accompanying voiceovers) seem stilted and contrived. In addition, while the key roles are (crucially) played by some very talented actors (e.g. Edward Norton and Guy Torry), some other actors are merely tolerable (e.g. Edward Furlong, Avery Brooks) and others still rather painful to endure (e.g. Fairuza Balk). The ending of the film may also be guilty of the charge that it misleadingly suggests racism as a uniformly symmetrical phenomenon. For more on the notion of false racial symmetries, see Blum (forthcoming).
} 
in which his conversion is presented is in fact subtler than many critics have allowed: Derek's transformation is not artificial or implausible but is depicted as resulting from a cumulative series of emotionally powerful life events and personal engagements. It is certainly true that it is not represented in the way some would seemingly have preferred, i.e. as straightforwardly resulting from a process of gradual intellectual improvement in Derek's reasoning on questions of race and politics. However, I'll conclude by arguing that the decidedly emotional basis of his moral evolution is both refreshingly realistic and not a hindrance to accepting his conversion as rational. ${ }^{2}$

\section{Cinematic Seduction}

Kaye, who's used to selling cars and cigarettes on British TV, shoots Derek the Hater as lovingly as he would a new Volkswagen. Derek is peddling malevolence, and Kaye can't see that he's helping to nail the sale.

- Manohla Dargis (L.A. Weekly, November 05, 1998) ${ }^{3}$

$A H X$ is a film that skillfully utilizes various techniques to present the immoral protagonist quite attractively. ${ }^{4}$ Manohla Dargis is surely right that director Tony Kaye's skill for crafting hip and stylish commercials is used to full effect as the film begins: the black-and-white flashback sequence showcasing Derek's response to an attempted car theft is quite striking in its sleek polish, with the seamless merger of sex and violence, and there is the distinct sense that we are being sold this character (and perhaps this lifestyle). For many viewers this is an understandably troubling aspect of this film. After all, we learn almost immediately that Edward Norton's character (Derek Vineyard) is a hate-filled neo-nazi skinhead who is not above brutal murder in response to petty crime on the part of those he deems inferior.

Perhaps making matters worse, the techniques and imagery employed to glamorize this neo-nazi recollect what has come to be called "fascist aesthetics." Ever since Susan Sontag's highly critical discussion of Leni Riefenstahl ("Fascinating Fascism") appeared in the New York Review of Books (in 1974), various critics and academics have applied this label to a wide variety of politically suspect works which seem to place particular emphasis on the themes of power, purity, health, beauty (in particular the beauty of a powerful and healthy human body). While Sontag never offers anything close to a list of necessary and sufficient conditions for a work to embody fascist aesthetics, some of her remarks certainly bring to mind aspects of the portrayal

\footnotetext{
${ }^{2}$ Note that I will not provide an argument that Derek's abandonment of racism was rational and his prior racism irrational. I take the irrationality and immorality of racism as a given here, and I understand the film critics that I respond to as all sharing that belief. My target will not be either the moral skeptic or the defender of racism, but rather the viewer who worries that the emotional nature of Derek's conversion taints its legitimacy.

${ }^{3}$ http://www.laweekly.com/1998-11-05/film-tv/skin-deep

${ }^{4}$ There was a well publicized conflict between the director Tony Kaye and the studio over the final cut of $A H X$. In the end, the cut that the studio released appears to be a version of an early cut by Kaye with some additional changes made by cutter Jerry Greenberg, producer Michael De Luca, and actor Edward Norton. Kaye's initial complaints that there were very significant differences between his versions and the released version appear to have been overblown. A fuller account of these matters can be found at: http://moviecensorship.com/report.php?ID=45661
} 
of Derek we get in the black-and-white flashback sequences from American History X:

Fascist aesthetics include but go far beyond the rather special celebration of the primitive to be found in The Last of the Nuba. More generally, they flow from (and justify) a preoccupation with situations of control, submissive behavior, extravagant effort, and the endurance of pain; they endorse two seemingly opposite states, egomania and servitude. [...] Its choreography alternates between ceaseless motion and a congealed, static, "virile" posing.

Fascist art displays a utopian aesthetics - that of physical perfection. Painters and sculptors under the Nazis often depicted the nude, but they were forbidden to show any bodily imperfections. Their nudes look like pictures in physique magazines: pinups which are both sanctimoniously asexual and (in a technical sense) pornographic, for they have the perfection of a fantasy. ${ }^{5}$

There is no doubt that Derek is deliberately presented to us as embodying both great power of will and something close to an ideal of physical perfection. And he is repeatedly framed by the camera in a manner that really does resemble shots of models posing. This in itself, however, doesn't distinguish his presentation from that of countless superheroes in many recent cinematic comic-book adaptations. What makes his mode of presentation more explicitly that of nazi Übermensch rather than "All American" Superman is, of course, the swastikas (in his bedroom and on his chest) that quickly reveal he's a neonazi skinhead.

While I can't do justice to the intricacies of her influential essay here, I think some skepticism regarding Sontag's vague and somewhat convoluted characterization of the themes and features that embody "fascist aesthetics" is probably in order. (To be blunt, I'm not always convinced she is gesturing at a stable category, even if it is awfully tempting to throw around the phrase "fascist aesthetics" when discussing a movie like 300. ${ }^{6}$ Regardless of whether she has supplied us with a generally reliable tool of aesthetic criticism, however, I still think it is worth considering American History $X$ in light of a particular fascist aesthetic sensibility. This is because $A H X$ is something of a special case - it goes beyond simply combining some hazy themes of power, purity, beauty, and health with an obviously fascist character. It also selfconsciously depicts that character in a stylized manner that naturally brings to mind the quite specific examples of Riefenstahl's infamous propaganda films for the Nazi party. The deliberately high-grain and high-contrast black and white photography, the repeated use of slow-motion footage, low-angled shots, distortive wide-angle lenses, and slick editing employed in $A H X$ 's "flashback" sequences, combined with a choir-filled quasi-operatic score that (superficially, at least) mimics the Wagner compositions beloved by both Hitler and Riefenstahl, make it quite hard for anyone familiar with Triumph of the Will or

\footnotetext{
${ }^{5} \mathrm{http}: / / \mathrm{www}$. nybooks.com/articles/9280

${ }^{6}$ An excellent critical discussion of Sontag's essay can be found in Rollyson (2009). He expresses a sensible concern over whether her notion of "fascist aesthetics" is usefully distinct from some notion of the pastoral (perhaps combined with an extra dose of machismo). Also, while I've expressed skepticism regarding Sontag's category of "fascist aesthetics," this skepticism does not extend to the usefulness of investigating the degree to which Hitler's fascism was itself shaped by aesthetic ideals (of beauty, purity, etc.). Peter Cohen's 1989 documentary The Architecture of Doom offers an absorbing and thorough consideration of this idea.
} 
Olympia to not suspect an intentional reference to those notorious films. ${ }^{7}$ (The basketball sequence in $A H X$ in particular evokes the athletes of Olympia.) Such suspicions turn out to be fully justified, as Edward Norton admits in an interview:

For me, that was impetus to make him physically, intellectually, everything larger than life and for Tony [Kaye- the director], to realize those flashbacks in a highly stylized form, like the black and white and those almost Leni Riefenstahl sort of shots of this guy. ${ }^{8}$

This aspect of the film amounts to more than just interesting trivia - If one is worried that American History $X$ is doing something morally dodgy in presenting its neo-nazi protagonist as stylishly and alluringly as possible, it is not irrelevant to note that those seductive cinematic techniques were drawn, in part, from the most famous works of Nazi propaganda. Indeed, with this recognition a successful defense of the film's moral worth can start to look increasingly unlikely.

\section{Hypocrisy?}

Given the extent to which $A H X$ gains cinematic power from the depiction of an idealized neo-nazi protagonist that is achieved through techniques directly inspired by the preeminent Nazi filmmaker, perhaps Manhola Dargis' concerns (expressed in the quotation that began the last section) about the ultimate message taken away from the film are well placed. But maybe the situation is even darker than she suggests. As critical as she is, Dargis does at least imply that the "selling" of Nazism by the film is unintentional. Some critics have gone beyond Dargis in their scorn, however, and have doubted the sincerity of the motives lying behind the work:

But what's worst about it is its rank, repellent hypocrisy: It not only allows its fantasy versions of American Nazis to spew their blackest, cruelest vomitus of hatred but it takes energy and vitality (and ticket-selling notoriety) from the electricity of that hatred; then it demurely pretends to disapprove in the last few minutes.

- Stephen Hunter (Washington Post, October 30, 1998) ${ }^{9}$

I think it is worthwhile to spend some time considering these claims that $A H X$ engages (knowingly or unknowingly) in a kind of hypocrisy in sexing up and glorifying the same lifestyle it ultimately claims to condemn. The charge of cinematic hypocrisy is one that clearly can have merit. I'm sympathetic to Victor Perkins' similar complaint regarding The Bridge on the River Kwai:

\footnotetext{
${ }^{7}$ In conversation I've encountered some who criticize the division of the film into black-and-white flashbacks and subsequent color sequences. The complaint is that the ploy is too heavy-handed and obvious in delivering a visual pun (i.e., "he used to see the world in simply black and white, but now his vision is richer...") My own view is that perhaps this aspect of the film would have struck me as crude on its own (employed just to make that point), but combined with the way in which it also allows the filmmakers to divide the film into a Riefenstahl-influenced segments and more conventional segments it is actually a clever and successful device.

${ }^{8}$ http://www.edward-norton.org/audio/ahxclips.html

${ }^{9}$ http://www.washingtonpost.com/wp-srv/style/longterm/movies/videos/americanhistoryxhunter.htm
} 
Many filmmakers have exploited this contradiction between declared intention and actual effect. Their pictures become elaborate and unscrupulous exercises in self-deception. Perhaps the most notable example is The Bridge on the River Kwai. Carl Foreman's dialogue repeatedly advertised its interest in establishing the futility of war, the hollowness of victory. But the picture's emotional dynamics invited us to share in the excitements, tensions, and triumphs offered by the action. War was said to be futile and experienced as glorious, victory was said to be empty and felt to be magnificent... ${ }^{10}$

While granting the possibility for such hypocrisy in a work of art, I reject the charge as directed at $A H X$. The target of the film is racist neo-nazi extremism, and while early on the film clearly offers a romantic and heroic depiction of its racist protagonist, what is being romanticized is primarily the character Derek Vineyard, not the racist ideology he embraces but eventually rejects. One reason the film is so effective is that it does not shy away from showing the protagonist as someone who embraces a nazi ideology but is, at the same time, charismatic, brave, intelligent, eloquent and attractive. What the film ultimately endorses is the idea that someone that cool, strong, and smart need not be a racist or a fascist. (We need not conclude that neo-nazi Derek represents a "package deal," so to speak.) ${ }^{11}$ What we come to see as the movie unfolds is that there was indeed no necessary link between the qualities in the protagonist that are genuinely admirable and the hateful racism he previously embraced. Beyond that, many of the values we admire in Derek (e.g. his integrity, his sensitive intelligence, and his capacity for real compassion) are shown to be a poor fit with the white supremacy movement he comes to reject. The film's structure and Derek's characterization is such that, for Derek to fully develop as the hero, it is both natural and inevitable that he shed the morally pernicious ideology to which we first find him attached. ${ }^{12}$

The film would have been significantly less successful had it not offered up such an enticing initial picture of its protagonist. ${ }^{13}$ Derek's glamorization in early scenes (e.g. the burglary/shooting scene and the basketball game triumph) allows for a high degree of engagement from the audience, and it is in part because we are initially primed by the camera to find him alluring that his eventual acts of grossly disproportionate violence and retribution strike us as so genuinely horrifying. ${ }^{14}$ This isn't to deny that the film begins with Derek committing terrible acts of violence, but my sense is that Derek's initial shooting of the attempted car thieves does not inspire much reflection or disapproval in the audience - retribution and guns (a blazin') being typical enough movie fodder for us to more or less (for better or worse) grant

\footnotetext{
${ }^{10}$ Perkins (1993, p. 149) Consider also a more recent example: Fight Club offers up a slick and seemingly edgy denunciation of consumerism while cynically exhibiting product placement throughout the film.

11 This is stark contrast to most powerful works of political propaganda, where the goal is indeed to make the notion of the "package deal" seem mandatory: the message is often one which suggests that all of the attractive aspects of the vision presented are inseparable from the specific political ideology being peddled.

${ }^{12}$ It is a commonly espoused idea that we are often drawn to "bad" fictional characters because they are immoral. While I don't want to deny that some viewers might be attracted to Derek because they take him to be evil, for reasons nicely laid out by Smith (1999) I think a genuinely perverse allegiance towards an immoral character is less common than often believed.

${ }^{13}$ I avoid using the problematic (but tempting) term "identification" for reasons offered by Carroll (1990, 2008) and Smith $(1995,1999)$. However, a sensible defense of the notion of identification can be found in Gaut (1999) and a related defense of empathic engagement is offered by Coplan (2004).

${ }^{14}$ For a discussion of the ways in which film can prep the audience to be receptive to narrative appeals to particular emotions, see Noël Carroll's discussion of “criterial prefocusing” in Carroll $(1998,2008)$.
} 
him a pass, especially given his romantic/heroic portrayal. It is what comes later that effectively get us to question our allegiance to this protagonist. In particular, the unhinged quality of Derek's rage and abuse of his sister during the dinner-table scene, and the astonishingly gruesome killing on the curb (an act which represents the logical extreme and ultimate culmination of his hatefilled creed), make it all but impossible not to be shaken into seriously rethinking the degree to which Derek deserves any allegiance. ${ }^{15}$

Because the film had earlier (quite carefully) fostered an attachment to Derek, these moments of violence lead us to naturally step back and question just what we have signed on to in sympathizing (even just in part) with this previously attractive character, and we then become substantially invested in tracking his development through the course of the narrative. (Our horror is not just at what he does, but at ourselves for having found him appealing, and this gives us a particularly robust motive for wanting to see how his story unfolds.) When he eventually comes to abandon his earlier ideology, his transformation is moving in no small part because of both our initial attraction to Derek and the subsequent ambivalence and soul-searching provoked in us by Derek's vicious actions. ${ }^{16}$

Consider that the movie could have presented all the racist characters (including Derek) as uniformly dumb and/or evil, and it would certainly have been "safer" and less controversial if it had gone this rather conventional route. However, it would not be nearly as interesting or forceful a film. On the contrary, simply demonizing the racist characters would have potentially been immoral in irresponsibly characterizing them as utterly alien to the viewer (thus suggesting that such moral failings fall prey only to others, not us).$^{17} \mathrm{AHX}$ is guilty of idealizing the protagonist rather than demonizing him, but this idealization is in fact integral to the larger (virtuous) goals of the film. An unappealing Derek would have made for a decidedly less effective (and so ultimately less moral) film. ${ }^{18}$

\footnotetext{
${ }^{15}$ Our shift in response here is not just due to the difference in the degree or type of violence: in these latter scenes we actually hear the victims yelling in pain, and we are shown their fearful faces to a degree lacking in the initial shooting sequence. Through highlighting (or "emotively prefocusing on") the victims' responses, the violence is now presented in a decidedly more intimate manner, and this makes it much harder to simply enjoy it (and dismiss it) as standard action movie fare. (The earlier attack on the Korean grocery is similarly intimate in showing us the terror of the victims, but it doesn't show us Derek committing those acts. It manages, however, to provoke a deep unease and revulsion that the subsequent scenes of Derek's violence build on and solidify.)

${ }^{16}$ cf. Jollimore and Barrios (2004, p.38) "By showing how characters with whom a reader identifies can be capable of actions that the reader finds herself morally condemning, a literary work can allow the reader to engage in self-criticism in a much more effective manner than is normally possible. It is in allowing for this type of deep self-examination and criticism, we believe, that literature can most effectively display its moral dimension."

${ }^{17}$ In contrast to $A H X$, consider the more recent film This is England. In that film, the main racist character (Combo) is a fairly crude and generally unlikable caricature whose racism and racist violence is, in large part, explained away in a rather naïve pseudo-psychoanalytic manner (i.e., he's really just frustrated that he can't get the girl...) While I think This is England has significant virtues, its depiction of the source of Combo's racist violence is not one of them. Granted, the film does not set out to provide the sort of strong moral message intended by $A H X$ - I mention it only to show a less successful depiction of a racist skinhead that certainly avoids the charge of making the character too alluring, but perhaps at the cost of offering a depiction that makes it quite easy for viewers to dismiss (with smug superiority) the racist character as beneath them.

${ }^{18}$ It would be hard to overstate the importance of Edward Norton's acting to the success (moral and aesthetic) of this film: his remarkable ability to depict both Derek's ferocity and sensitivity is a huge part of what makes the character gripping and credible. (It is a curious fact that the relevance of acting is rarely discussed alongside other cinematic ingredients (like direction and the screenplay) when the moral significance of films is under review.)
} 
At this point I hope it is clear that I take the ultimately moral goals of $A H X$ to justify its seductive cinematic means. Further, I think the morality of the film makes worries over the influences of Riefenstahl's aesthetics misguided. What makes her works so hauntingly problematic is not the (still quite powerful) techniques, but that such aesthetically effective techniques were wedded to such evil ends. ${ }^{19}$ In adopting a more noble end, $A H X$ demonstrates the potential independence of those techniques from an immoral ideology. (I realize this is a debatable claim, for one might argue that the techniques themselves, in involving emotional arousal of the viewer, are the stuff of coercive manipulation rather than rational persuasion, and thus are intrinsically suspect. This is a popular and important charge, and one that I will return to later once we have considered the role of the emotions in $A H X$ 's protagonist's development. A defense of the legitimacy of emotional persuasion in that context will turn out to have helpful ramifications for answering such questions about the legitimacy of emotionally persuasive works of art.)

\section{Romper Stomper}

I've denied that $A H X$ is guilty of the charge that it hypocritically exploits the allure of its nazi protagonist while claiming to denounce his worldview. Backing up this denial will require a more careful consideration of how the plot of the film unfolds. In particular, we'll need to look more closely at the presentation of Derek's moral conversion. First, however, I think it is useful to contrast $A H X$ with another similar film, one where the charge of hypocrisy holds significantly more weight. The 1992 Australian film Romper Stomper was clearly an important influence (both in subject matter and style) on $A H X$, and is notable for also offering a "break out" role for a very talented actor (Russell Crowe). While it too presents us with a buff (often semi-nude), sometimes eloquent, heavily tattooed racist skinhead as a protagonist, the film gains a certain energy and power from its edgy choice of anti-hero while never directly challenging the deeply immoral worldview of that character or his comrades. Worse still, the film at times seems to (albeit implicitly and indirectly) endorse the racist ideas it flaunts. While fully making the case for this charge would take a separate paper, let me briefly highlight two portions of the film that I find particularly troubling:

\section{The Rumble}

The major early action sequence, in which we see some Vietnamese youth battle the skinheads, is one where the "foreigners" are shown to be (rather dramatically) flooding into the scene, a seemingly unending tide of nameless faces. They are strangers to us, while we have had some time to cinematically bond with the skinheads, so the audience quite naturally takes the side of the (quick to become underdog) skins, rooting for their victory, in what is otherwise a pretty standard but successful fast-paced and intense gang fight scene. Our allegiance towards the skins is further strengthened when the battle travels back to their living space and it becomes a question of them defending their (quite literal) home turf against these foreign invaders.

\footnotetext{
${ }^{19}$ A rich exploration of the philosophical issues raised by Triumph of the Will's disturbing marriage of beauty
} and evil can be found in Devereaux (1998). 
Note that this extended action sequence occurs almost immediately after we have heard the hero (Hando, played by Crowe) offer his first on-screen pronouncement of his nazi philosophy. In that speech he denounces the recent waves of immigration, referring to the immigrants as "boatloads of human trash," emphasizing their growing numbers, and blaming them for most of his country's woes. (He concludes: "I don't want to go the same way as the fuckin abo.") A carefully constructed parallel has been drawn by the filmmakers between this earlier speech and the visual rhetoric of the subsequent action sequence, a parallel which provides visceral emotional support for the prior explicit justifications offered for racism. The result here is not one that need be consciously registered by the audience to be effective. It can (and I suspect often does) function as what Perkins has called an "invisible effect," subconsciously helping to further align the viewer with the skinheads (and their racism) through supplementing the force of Hando's hate speech with apparent evidential backing (i.e., we see visualized a small-scale depiction of the supposed large-scale threat: the outside invaders really do seem to be flooding in and taking over... $)^{20}$

\section{The Ending}

Consider also the appearance of the Japanese tourists at the very end of the film: they too are depicted as pouring off an (apparently stuffed) tour bus in large numbers, and they come stereotypically bearing large numbers of cameras and camcorders, gawking and clicking from above as the "Aryan" protagonists battle it out on the beach below. The director (Geoffrey Wright) has claimed that he intended this aspect of the ending to be ironic, going so far as to claim that his point was to contrast the successful and industrious Japanese with the ultimately self-destructive white characters. ${ }^{21}$ That the basis for this "irony" relies on a rather tiresome racist stereotype seems not to have struck Wright as problematic. At any rate, the irony of the scene seems to be lost on most viewers, and what they come away with instead is just more rhetorical support for the theme of foreign invasion that undergirds the racist sentiments of the skinheads.

In addition to the disconcerting aspects of the film I've just focused on, it is relevant that there is no ultimate conversion offered in Romper Stomper. ${ }^{22}$ While one charismatic skinhead (Davey) eventually abandons the racist gang, his motivations seem to be based as much on pragmatic romantic considerations as anything else (and his commitment to the cause never seemed particularly robust to begin with). Hando himself is never shown as questioning his nazi philosophy. Wright has given conflicting rationales for the lack of an explicit moral judgment against Hando's worldview: on the dvd commentary he suggests that he wanted to avoid heavy-handedness and leave matters for the audience to decide (though he implies that the wrongness of the racism should

\footnotetext{
${ }^{20}$ Perkins (1993). Adding even more weight to this rationale for Hando's racism, we are also shown that the action sequence was triggered by the appearance of a small group of Vietnamese youth at a local skinhead watering hole, and it is revealed (to us, though not to the skinheads) that the youths are there because their older relatives will soon be purchasing and "taking over" the bar.

${ }^{21}$ Wright, Geoffrey, commentary. Romper Stomper. Dir. Geoffrey Wright. 1992. DVD: 2002, $20^{\text {th }}$ Century Fox.

${ }^{22}$ This isn't to suggest that such a conversion would have been necessary for the film to usefully address Hando's racism. For a thoughtful discussion of a film (Do the Right Thing) that manages to critically engage its audience through presenting a "sympathetic racist," see Flory (2008).
} 
be obvious enough). In an interview with the New York Times he suggests a slightly more moralistic approach:

Mr. Wright agreed that evil can be attractive. Speaking by telephone from Melbourne, where he is finishing his second film, he said he wanted to transport audiences into the middle of a gang and invite a mixture of emotions; excitement, curiosity and, at the end, revulsion at their own feelings. ${ }^{23}$

If Wright is being sincere in this interview, I think he pretty clearly failed in his goal: someone drawn to Hando and his gang though their romantic portrayal in Romper Stomper is given little reason by the film to feel challenged, let alone revulsion. Instead, the film provides more than adequate resources for the viewer sympathetic to neo-nazism to find Hando something of a tragic hero, flawed (and thus doomed) but nonetheless noble in his racist quest. ${ }^{24}$ Further, as I suggested earlier, it is my contention that Romper Stomper quite problematically ends up glamorizing not just the (unapologetic) racist, it glamorizes the racism itself. In this way, despite many similarities, it is a very different film from American History $X^{25}$

\section{Intellectual Asymmetry}

I want to return now to worries about the way in which $A H X$ depicts its protagonist's development. A quite striking feature of $A H X$ is that it is a film about the maliciousness of racism that presents us with an uncommonly smart and eloquent racist (significantly more eloquent, in fact, than Hando in Romper Stomper). Beyond this, to the extent we get arguments about race in this film they are almost always arguments offered by the racists. Non-racists do not get "equal time" and are certainly not presented as offering better reasons for their view. We also do not hear Derek, upon abandoning his racist position, offer anything significant by way of argument to counter the superficially powerful rhetoric we saw him spout earlier. This feature of the film has been singled out by more than one prominent critic as problematic. Consider the remarks of Roger Ebert:

He's assigned to the laundry, where his black co-worker (Guy Torry, in a wonderful performance) gradually--well, begins to seem human to him. But there's a strange imbalance in the conversion process. The movie's right-wing ideas are clearly articulated by Derek in forceful rhetoric, but are never answered except in weak liberal mumbles (by a Jewish teacher played by

\footnotetext{
${ }^{23}$ The New York Times, June 6, 1993, “An Australian Actor Tries Life as a Neo-Nazi Punk”, By Amruta Slee.

${ }^{24}$ It is not an accident that on the film-based threads on neo-nazi internet discussion boards (like stormfront.org), Romper Stomper is quite popular among actual racist skinheads, while American History $X$ tends to be dismissed as anti-racist propaganda created by the Hollywood machine.

${ }^{25}$ As with $A H X$, my overall judgment of this film is complicated: though I find Romper Stomper morally flawed, it is an impressively crafted film that delivers superlative performances from Russell Crowe and Daniel Pollock. Also, I take my discussion of both films to be compatible with several approaches to questions of the relation between moral and aesthetic value, but Carroll's "moderate moralism" is perhaps the best fit. Cf Carroll (2008).
} 
Elliott Gould, among others). And then the black laundry worker's big speech is not about ideas and feelings, but about sex and how much he misses it. ${ }^{26}$

Baltimore Sun critic Ann Hornaday has similar complaints:

Most problematic is Derek's conversion, which begins at the hand of a black inmate (a very engaging Guy Torry) who bonds with him over basketball and babes and ends with a brutal rape involving his fellow white supremacists. Considering that the way to Derek's heart is through his mind, it's distressing that his beliefs are changed not by an appeal to his logic but by something as base as sexual violation or as trivial as a shared interest in sports. [...] The great disappointment of "American History X" is that, as carefully as it builds the case for racism, it isn't nearly so meticulous when it tears it down. ${ }^{27}$

And here the protest is echoed once again, this time by SFGate's Mick LaSalle:

That's where the movie disappoints. David McKenna's script is great at presenting a descent into neo-Nazihood as a partly intellectual process. But Derek's way back is described solely in emotional terms. In prison, the other skinheads are mean to him, while a pair of black men save his life. That's nice, and certainly that could change his racist feelings. But one waits in vain for Derek to renounce his past thinking. We had to watch him think his way in. We should see him think his way out. ${ }^{28}$

I agree with these critics that this intellectual asymmetry in the film is remarkable and noteworthy, but I don't think that it is a flaw. Instead, I'd like to suggest that it is, perhaps surprisingly, a significant virtue of the film.

One of the difficulties in fighting against racist ideology is that the attitudes are often so seemingly primal and apparently intractable. The arguments offered by racists are (pace LaSalle) usually mere window dressing and rarely what drove them to embrace their hateful and reactionary worldview. ${ }^{29}$ While certainly not impotent, argumentation and deliberation really only go so far in bringing about the sort of weighty moral conversion involved in giving up a racist perspective. This point holds not just for extreme racist views, but applies generally to much of our moral lives, as has been eloquently noted by Nomy Arpaly:

Anyone who has tried to convince someone of a moral truth without success via argumentation, only to watch that person undergo a conversion years later as a result of a significant life event or watching La Strada, knows examples of morally important changes that happen without deliberation. ${ }^{30}$

\footnotetext{
${ }^{26}$ Chicago Sun-Times, October 30, 1998.

http://rogerebert.suntimes.com/apps/pbcs.dll/article?AID=/19981030/REVIEWS/810300301/1023

${ }^{27}$ Baltimore Sun, November 13, 1998.

http://articles.baltimoresun.com/1998-11-13/features/1998317022_1_history-x-edward-norton-derek

${ }^{28}$ SFGate, October 30, 1998.

http://www.sfgate.com/cgi-bin/article.cgi?file=/chronicle/archive/1998/10/30/DD7538.DTL

${ }^{29} \mathrm{cf}$. Gaita (1998, p. 62): "Study after study of racism tells us that the rationalizations racists offer to support

their attitudes toward those they denigrate are not vulnerable to argument and evidence in the ways that

reckless generalizations and careless inferences usually are."

${ }^{30}$ Arpaly (2003, p. 23)
} 
This film accurately depicts this aspect of moral phenomenology in suggesting that Derek's eventual evolution and transformation is not primarily a matter of being convinced by valid arguments. Rather, we see him undergo various experiences that help him to eventually better understand the poverty of his previously narrow and blinkered vision of the world, experiences which provide him the resources to imagine a better way of life. ${ }^{31}$ In the next section I'll consider those experiences in more detail and attempt to assuage the worries of those critics who have fretted that Derek's transformation is somehow undermotivated or under-described in the film.

\section{Moral Conversion}

Derek's transformation is so unbelievable that Kaye might just as well have created a pop-song montage showing Derek bonding sentimentally with black inmates. He learns that the prison's white-power advocates are simply selfinterested hypocrites, while the black guys are, uh, nice. [...] So for no very clear reason, Derek's prison experience utterly changes him.

-Andy Klein (Dallas Observer, November 12, 1998) ${ }^{32}$

Derek's metamorphosis, which on the surface recalls the story of Thomas Leyden, a former racist skinhead now working with the Simon Wiesenthal Center, isn't just abrupt, it's ridiculous. Leyden, once a skinhead recruiter and Tom Metzger pal, took a couple of years to change his world. Four months before he's up for review, Derek gets brutalized by some white goons, buddies up with a wisecracking black guy (Guy Torry) and decides, gee, maybe Hitler had it wrong after all.

-Manohla Dargis (L.A. Weekly, November 05, 1998)

My claim that this film succeeds in presenting a realistic moral conversion is not uncontroversial. ${ }^{33}$ Beyond worries about a lack of on-screen anti-racist cogitation, several critics have characterized Derek's conversion as hackneyed and overly abrupt. Such critics tend to reduce the narrative of his conversion down to only one to two events or insights. This simplistic dismissal ignores that the film actually tells a more nuanced story about Derek's moral transformation. Though some of these plot points are more subtle than others, there are multiple relevant factors offered to the viewer (spread out over the course of his three years in prison, not just the four months Dargis cites):

\footnotetext{
${ }^{31}$ This emphasis on Derek undergoing (seemingly passive) experiences rather than (active) willed deliberation might arouse worries about Derek's responsibility (either for his earlier racist views, or his later conversion). This is a very large topic that I can't adequately pursue here. Safe to say I think an account of our moral thought that emphasizes its emotional and non-deliberative aspects is compatible with a sensible acknowledgment of Derek's free will and moral responsibility. (Arpaly (2005) discusses questions of responsibility at length, and I'm sympathetic to much of what she says.)

32 http://www.dallasobserver.com/1998-11-12/film/don-t-know-much-about-history

${ }^{33}$ Though lest you get a misleading impression from all the rather critical review excerpts I've presented, I should point out that a lot of leading critics quite liked the film, e.g. Roger Ebert (despite his reservations mentioned earlier), Gene Siskel, Owen Gleiberman, Jay Carr, and Janet Maslin. (It also has plenty of fans who aren't professional critics: it currently ranks at \#37 in IMDB's “Top 250" movies as voted by users of that site.)
} 
a. Derek gradually perceives and acknowledges the effects his actions and lifestyle are having on his family. (This process is hinted at during his bedside discussion with his former teacher Sweeney, and earlier through his mother's visitation in prison, but I think we see the first glimmer of his self-awareness on this issue in his reaction to the police restraining his brother immediately after the murders.)

b. He is made acutely aware of being a "minority" in prison (humorously by fellow prisoner Lamont, not so humorously by the guard on his first day in prison).

c. He comes to recognize elements of structural racism (something he previously seemed oblivious to) in the obviously unjust sentencing of Lamont.

d. Through discovering their drug dealing, he realizes that the white supremacist prisoners lack the integrity he naively attributed to the movement.

e. He learns firsthand that a "might makes right" fascist worldview, so attractive when one of the "mighty," is a philosophy which even he can come to suffer under, as he does in the prison rape. (In this way his rape serves to show more than just that the white power folks aren't his friends...)

f. He (slowly) genuinely befriends his coworker Lamont, and this ultimately results in Lamont helping to protect him from further abuse in prison.

g. As mentioned, when in prison he is pushed by Sweeney to consider the larger ramifications of his choices, and, once he is released, Sweeney further encourages him to recognize his responsibility not just to his family but to the larger community.

Now any such a breakdown of plot elements is no replacement for the film itself. ${ }^{34}$ My point here is just to remind viewers that Derek's conversion involves more complexity and subtlety than critics like Klein and Dargis seem willing to allow. ${ }^{35}$ As a result of these various events Derek gradually matures in prison such that he comes to realize that the hatred he had placed at the center of his being was neither mandatory nor desirable. Each of these experiences helps, to varying degrees, to prod Derek into an eventual shift in perspective.

Derek's friendship with his black coworker Lamont, someone he would previously have dismissed as "the enemy," is certainly depicted by the film as a major force behind his gradual transformation, though, as shown above, the relevance of this relationship is multifaceted, and it can't be accurately reduced to simply "buddying up" with a "wise-cracking black guy." Also, though this pairing has come in for ridicule from some critics, it is in reality a far from an unrealistic plot device - consider again some relevant remarks from Arpaly:

Very few people who give up racist prejudices, for example, give them up via a process of deliberation. More often, the irrationality of their prejudice dawns

\footnotetext{
${ }^{34}$ Further, this list fails to convey the power of the work summarized in part because the unique ability of narrative art to invoke emotion is lacking from any such schematic outline. For more on art and narrative's essential link with emotion see Robinson (2005).

${ }^{35}$ I do admit that viewers might need reminding: I'm sympathetic to the complaint that the pace and the rhythm of this portion of the film causes some viewers to perceive the conversion as happening more quickly than it actually does (given the time frame of the narrative).
} 
on them after spending long enough with people of the relevant race and realizing, bit by bit, that they are very similar to themselves. ${ }^{36}$

In Unprincipled Virtue Arpaly offers a sophisticated defense of the legitimacy of such "dawning processes," and she convincingly argues both that these processes are both more common than many philosophers seem willing to acknowledge, and that they are rightly regarded as rational despite the fact that they often don't involve deliberation (and can involve emotion). ${ }^{37}$

One might resist Arpaly's conclusion, however, and insist that perhaps these encounters are relevant because they eventually do culminate in some sort of explicit deliberation and principled inference, and that this is what actually justifies the racist's change of heart as rational. Yet this type of diagnosis doesn't ring true to the phenomena, as Raimond Gaita has pointed out:

[The racist] is not expressing an opinion that has been built up, by him or by others, from observation of similar instances. It is true that racists sometimes give up such denigratory beliefs because they have had certain experiences, generally because they have lived with the people they had denigrated. But 'experience' is a tricky word, just as 'capacity' is a tricky word. For complex reasons we assimilate it to the concept of the empirical as that lends itself to the idea of building up understanding by means of generalizations supported by confirming instances. But coming, through living with a people, to see dignity in faces that had all looked alike to us, to see the full range of human expressiveness in them [...] that is quite different from coming to acknowledge that they score well on IQ tests. We do not discover the full humanity of a racially denigrated people in books by social scientists[.] $]^{38}$

Day by day, Derek gradually comes to better understand and appreciate Lamont's perspective, and this complicates his prior simplistic vision of "us vs. them." 39 The successive interactions inevitably bring out shared interests (women, sports, humor, the crappiness of their job and prison life generally) and make it harder and harder for Derek to simply dismiss Lamont's full humanity because of his race. Perhaps some degree of ratiocination and "cool" deliberation is at work in Derek's transformation, but any realistic account of such a change needs to go beyond arguments and acknowledge the vital role that concrete lived experiences (and the emotion, perception, and imagination they involve) play in our moral commitments. ${ }^{40}$ Thus, in highlighting Derek's

\footnotetext{
${ }^{36}$ Arpaly (2003, p. 56) Cf. the filmmaker John Waters: "If you're traveling, you can't be racist," Waters says. "You can't be homophobic. I think the only way you can be racist or homophobic is if you never leave the neighborhood you were born in, and you hang around with stupid people. So I've always thought that someone who was really racist should be sentenced to travel, but that's not very practical." (http://www.indyweek.com/gyrobase/Content?oid=oid\%3A160709)

${ }^{37}$ A nice move in Arpaly's argument involves her pointing out that requiring deliberation as a condition of rational judgment seems to leave deliberation itself as lacking rational grounding. (We don't deliberate about whether to deliberate, after all.) Arpaly (2003, p. 57)

${ }^{38}$ Gaita (1999, pp. 66-67) Gaita goes on to conclude that, while social science books don't generally provide this sort of moral insight, works of fiction can: "If we discover [the full humanity of others] by reading, then it is in plays, novels, and poetry, in other words not in science but art." (p. 67) Presumably Gaita would allow that a film (such as $A H X$ ) is also capable of providing such edification.

${ }^{39}$ The emphasis that I (and Arpaly and Gaita) place on getting to know individuals of another race shouldn't be taken to suggest (naively) that such encounters guarantee moral improvement. Obviously many racists are all too capable of living alongside and interacting with those they despise. The point here is just that coming to know individuals is often an impetus to change, and further it appears to be significantly more efficacious than the presentation of (even very good) arguments to the racist.

${ }^{40}$ When philosophizing it is easy to forget that in reality it is not uncommon to view a need for deliberation (in order to be sufficiently motivated) as a moral handicap. After all, the person who has to deliberate or
} 
history of interaction with Lamont, and presenting it in the context of the other relevant factors mentioned earlier, $A H X$ offers us an eminently more plausible (and thus effective) depiction of a moral conversion than we would have been given had this film attempted the sort of rhetorical balancing game craved by those critics mourning the apparent lack of intellectual parity.

\section{A Better Life}

And the [conversion] process is completed during a visit from Sweeney, who asks him to consider whether anything he has ever done has made his life better. Derek concludes that it has not and his lesson, then, is that his political beliefs must yield to his self-interest, the conditions of his own existence. However obnoxious and dangerous the politics that Derek turns away from, the lesson the film ultimately offers is a repudiation of politics altogether: political views must be seen as separate from and ultimately secondary to one's own life and self-interest.

- Paul Smith, "American History X"41

With the nuances of Derek's moral transformation in mind we can now consider one final complaint about the film: that the "message" of $A H X$ is somehow crudely egoistic and self-centered. Those making this charge have latched on to Sweeney's question for Derek ("Has any of this made your life any better?") as well as Derek's remark to Danny that he was "so tired of being pissed off." ${ }^{2}$ Taken out of context, it is easy to see how such lines might suggest a pretty shallow and even morally offensive message that one is better off not being a neo-nazi simply because, well, being a racist (like being a nihilist in The Big Lebowski), is exhausting, and just not a smart way to maximize personal utility. Such an interpretation of these lines is far from compulsory, however, and I think a much more charitable and plausible reading is one in which these remarks are taken in a broadly Aristotelian sense. In other words, the "better life" gestured at by Sweeney should not be thought of just in terms of a life filled with more pleasant moments, but rather the "good life" as described by Aristotle, who argued that a genuinely full and satisfactory human life was incompatible with viciousness.

Aristotle famously proclaimed that an immoral agent cannot genuinely be happy, but as countless commentators have remarked the relevant notion of happiness here is not the pervasive modern one of pleasant conscious experience, but rather a much richer vision of a complete life, i.e. a life which has developed successfully and accordingly results in the flourishing of the individual. ${ }^{43}$ While a vicious and hate-filled individual may well be capable of

weigh reasons (pro and con) in order to convince himself not to commit a horrific crime is ordinarily taken to have fallen significantly short of being a moral paragon. This in itself should raises suspicions about any approach to practical reason that insists being responsive to the relevant moral reasons requires that sort of explicit ratiocination. (I owe this point to Michael McKenna.)

${ }^{41}$ Smith (2007, p.251)

${ }^{42}$ There's also Danny's reiteration of Derek's point as "Hate is baggage. Life is too short to be pissed off all the time."

${ }^{43}$ This broadly Aristotelian manner of understanding the relation between a good life and morality has many able recent defenders, and I won't take up space summarizing their responses to critics here - instead I'll simply assert my allegiance with this general approach. One interesting defense which invokes a recent Hollywood film for support is Joseph Kupfer's essay "Virtue and Happiness in Groundhog Day" in Kupfer (1999). 
experiencing pleasure, according to Aristotle such an individual is destined to a life that is in an important sense stunted. This is exactly the sort of insight we see Derek eventually achieve: his experiences in prison culminate in a gradual awareness that his racist ideology has really amounted to little more than fuel for years of pointless and destructive rage. Sweeney's question for Derek, then, turns out to be far from shallow, providing a catalyst for him to recognize a rather deep truth about the connection between virtue and a better life. This provocation from Sweeney is not something that functions in isolation, however; the question comes at the right time, after Derek has undergone an array of relevant experiences that place him in a position to see the wisdom of such a remark.

\section{Emotion and Rationality}

In describing Derek's conversion as resulting primarily from emotionally significant life experiences rather than straightforward intellectual argumentation and deliberation, I raise a natural concern among many who think of emotion as fundamentally at odds with rationality. The vision of the self which lies behind this concern, a vision in which our emotions are taken to be inherently suspect because they can conflict with and possibly undermine the (better) reasonable side of ourselves, is a very old one, stretching back at least to Plato and receiving a powerful articulation in the moral philosophy of Kant. ${ }^{44}$ It is also a vision that is clearly still very much a part of common sense. As tempting as this binary picture of the self is, however, it is in fact fundamentally misguided, as many philosophers, psychologists, and neuroscientists have pointed out. Rehashing the numerous impressive arguments against this classic divide is beyond the scope of this paper, but I do want to end with a brief sketch of some recent currents of thought to help quell the worries of those who suspect that my emphasis on the emotional factors at play in Derek's conversion undermines my assumption that Derek has been rational and made genuine moral progress in abandoning his old views.

One popular strategy for denying this vision of an irresolvable conflict between reason and emotion has been to argue that emotions are inherently cognitive, and so subject (like beliefs) to assessment as potentially rational. As Noël Carroll has put it: "reason is an ineliminable constituent of the emotions." 45 In recent years, it has become common for many philosophers working in the field to embrace some form of a "cognitive theory" of the emotions. Such approaches gain force from the fact that many emotions appear to involve both intentionality and cognitive appraisals: for example, anger is not usually regarded as simply a raw feeling - it seems to necessarily involve certain relevant beliefs and judgments (both regarding why I'm angry, and what I'm angry at). ${ }^{46}$ If it is true that emotions include a cognitive component, it

\footnotetext{
${ }^{44}$ I have in mind here primarily Plato's remarks in the Ion, the Phaedo, and The Republic that portray emotion as a dangerous threat to reason. At other points in his writings (e.g. the Laws) a more complicated picture of the relation between reason and emotion emerges.

${ }^{45}$ Carroll (1998, p.252)

${ }^{46}$ Some theorists go so far as to identify emotions with judgments, while others suggest emotion must at least involve belief. Others still claim only that emotion necessarily involves some degree of cognitive evaluation or appraisal. Robinson (2005) offers a good overview of these debates and defends her own original account of emotion as a process that involves both non-cognitive affective appraisals and cognitive monitoring.
} 
looks like a characterization of emotion as radically divorced from reason should be rejected.

While I'm sympathetic to some versions of the cognitive approach, debates over the proper theory of the emotions are quite contentious and complex, and I'm reluctant (especially given all that we still have to learn from empirical work on the topic) to throw my hat in with a particular theory here. Happily, I don't think we have to, for there is another option: rather than insist that emotions are fundamentally cognitive, we can attack the Platonic prejudice from the other side, and instead defend the claim that (flipping Carroll's formulation) emotion is an "ineliminable constituent" of proper reasoning.

This claim gets support from a variety of recent empirical work, much of it kick-started by Antonio Damasio's research (discussed in Descartes' Error) on the ways in which emotion seems necessary for successful practical reasoning. ${ }^{47}$ In that book, Damasio describes the case of a patient he calls Elliot, who suffered from a tumor which damaged tissue in the frontal lobe of his brain. After the tumor and damaged tissue were removed, those close to Elliot noticed significant changes in his personality. He seemed to irrationally abandon tasks arbitrarily, he showed a chronic inability to make basic decisions, he took on odd habits and behaviors, and he displayed a dangerous lack of judgment when it came to new projects and social relationships. What was striking in all this is that Elliot's performance on intelligence tests, despite his tumor and subsequent operation, remained above average - indeed he scored average or above-average on a whole gamut of standard psychological and neuropsychological tests. Yet he could not successfully manage most of the basic practical decisions required to get through an ordinary day.

After more tests and further research, Damasio came to a surprising conclusion: Elliot's difficulties in practical reasoning resulted from an abnormally reduced capacity for emotional responsiveness. The damaged portion of the his brain played a fundamental role in supplying and regulating emotional reactions, and without those resources Elliot could not make reasonable choices in real-life situations. A proper capacity for emotion turns out to be crucially tied to a normal ability to make decisions and reason successfully about one's own actions. (This includes reasoning that is straightforwardly self-interested, as well as practical reasoning motivated by more direct concerns for others.) Damasio has theorized that this is because our emotional memory and our emotional responses help us to "frame" real-world problems and choose from among the countless options we face when making decisions about how to act. Without the aid emotions provide in helping us detect the relevant features of a situation, we become quite feeble practical thinkers, for we are unable to narrow down our options to a manageable size. ${ }^{48}$

A diverse group of philosophers have pointed out that Damasio's research provides persuasive backing for a philosophical treatment of rationality that grants emotions a respectable role. Martha Nussbaum finds the research supportive of her generally Aristotelian approach and her longstanding commitment to defending the "intelligence of the emotions":

\footnotetext{
${ }^{47}$ Damasio (1995)

${ }^{48}$ Note that on some particularly cognitive views of the emotions, the basic sort of affect involved in the decision-making process might not rise to the level of genuine emotion (as opposed, that is, to mere affect). Following Damasio, I'll be using the term "emotion" more loosely so as to include this sort of affect.
} 
[Elliot] had cognitions and even, in some sense, evaluations: what he lacked was their eudaimonistic element, the sense of vital projects of his own being engaged. [...] How can one set priorities well in life, if no one thing seems more important than any other? Even though Elliott could reason his way through a problem, he lacked the kind of engagement that would give him a sense of what to do. [...] emotions provide the animal (in this case human) with a sense of how the world relates to its own set of goals and projects. Without that sense, decision making and action are derailed. ${ }^{49}$

Nomy Arpaly suggests that Damasio's findings bolster Arpaly's sustained attack on philosophical approaches to rationality that place a distortive and unrealistic emphasis on deliberation:

Brain-damaged nonfeelers, despite an unharmed ability to deliberate and reflect, make bad decisions because they are denied such feelingbased access to their own background knowledge in making those decisions. Thus, despite being able to deliberate, they end up doing things that no rational person would have done[.] ${ }^{50}$

While Patricia Churchland concludes that Damasio's research gives us grounds for rejecting an influential but excessively narrow economic model of rational choice:

The significance for choice of feeling, and of unaware biasing by feeling, has implications for the economists' favored model of "rational choice." According to this model, the ideally rational (wise) agent begins deliberation by laying out all the alternatives, calculating the expected utility for each alternative based on the probability of each outcome multiplied by the value of (goodies accruing to) each outcome. $\mathrm{He}$ ends by choosing the alternative with the highest expected utility score. In light of the data just considered, this model seems highly unsatisfactory. At best, it probably applies to a small range of highly quantifiable problems, but even then comes into play after "cognition cum feeling" brings to awareness the restricted set of "feels-reasonable" alternatives. At any rate, the economists' model is unlikely to come even close to giving the whole story of rational choice. ${ }^{51}$

The moral here seems to be that, while some types of (purely theoretical) reasoning may well be independent of emotion, a rather crucial subset (i.e., practical reasoning) is not. This is because our basic decisions (both selfinterested and moral) about how to act generally require emotional feedback without it we stumble, unable to detect the salient options before us. The traditional dichotomy is a fantasy: emotions are best construed as not the enemy of reason but a deep-seated ingredient of much reasoning.

\footnotetext{
${ }^{49}$ Nussbaum (2001, p. 117)

${ }^{50}$ Arpaly (2003, p. 59)

${ }^{51}$ Churchland (1998, p.241)
} 


\section{Residual Doubts}

My hope is that the preceding discussion helps to challenge the suspicions expressed by some critics regarding whether the presentation of Derek's transformation (a presentation that emphasizes emotional experiences over arguments) can possibly be adequate. While I think the concerns of these critics are misplaced, they are certainly comprehensible: despite the compelling evidence against it, the temptation to hold on to a picture in which rationality is starkly opposed to emotion is very strong, and the related Kantian estimation that moral thought is suspect to the degree that it is emotionally tainted seems an especially hard prejudice to shake. Consider a discussion of these issues by Jonah Lehrer in his recent book How We Decide. After summarizing Damasio's research and concluding that prior to Damasio's groundbreaking work "neuroscience assumed that human emotions were irrational," Lehrer claims that the case of Elliot shows us that "emotions are a crucial part of the decisionmaking process." $52 \mathrm{He}$ also goes on to criticize Plato, praise William James for his less "rationalist" and more emotion-friendly account of the mind, and describe several other recent studies and research projects which he thinks help us to appreciate "the wisdom of the emotions." 53 However, in a later chapter entitled "The Moral Mind," after canvassing research involving psychopaths which suggests that emotion plays a crucial role in distinctly moral thought, he feels compelled to say things like the following:

But all of these old conceptions of morality [in which rationality distinguishes between right and wrong] are based on a fundamental mistake. Neuroscience can now see the substrate of moral decisions, and there's nothing rational about it. (p. 172)

When you are confronted with an ethical dilemma, the unconscious automatically generates an emotional reaction. (This is what psychopaths can't do.) Within a few milliseconds, the brain has made up its mind; you know what is right and what is wrong. These moral instincts aren't rational- they've never heard of Kant- but they are an essential part of what keeps us all from committing unspeakable crimes. It's only at this point -after the emotions have already made the moral decision- that those rational circuits in the prefrontal cortex are activated. People come up with persuasive reasons to justify their moral intuition [...] But this reasonableness is just a façade, an elaborate self delusion. (p. 173)

The reasoning here (roughly) seems to be: moral judgments have an emotional basis, so (though they might be very useful and nice) moral judgments can't be rational. ${ }^{54}$ This line of inference is quite surprising, however, given Lehrer's earlier recognition of the emotional basis of all practical reasoning. Why does he now single out moral judgments for this sort of dismissive talk? (And it is

\footnotetext{
${ }^{52}$ Lehrer (2009, p.15),

${ }^{53}$ Lehrer (2009, p.26, p.41)

${ }^{54}$ Lehrer also suggests that, because it turns out that morality doesn't have a Kantian-like foundation in "pure reason," notions of moral objectivity and moral facts are also suspect: "This [the Kantian view] meant that morality was based on objective values; moral judgments described moral facts. But the mind doesn't work this way..." (p.172) He does not consider the reasonable possibility that moral objectivity may well be defensible on non-Kantian grounds.
} 
pretty clearly dismissive, after all, for in ordinary language to claim a decision or judgment is "not rational" is almost always to speak pejoratively.) It is telling that at no point in the book does he describe self-interested judgments as not being rational by virtue of their emotional substrate, but given that they too suffer from this emotional "taint," it seems that he ought to either admit that they are also not rational, or (preferably) he should revise his account of rationality to allow moral judgments to at least potentially fall within the scope of reason.

I take Lehrer's misleading remarks regarding the rational status our moral judgments to be in tension with the tenor of his (usually very sensible and insightful) general discussion of the relationship between emotion and reason. But perhaps there are independent grounds for limiting the realm of the rational to self-interested (i.e., non-moral) judgments and reasoning. ${ }^{55}$ This is certainly a popular presumption in economics and (to some extent) in common sense. What could justify such a restriction, however? If the thought is that selfinterest is natural while (say) a moral motive like compassion is not, this has been challenged by recent work in empirical moral psychology which Lehrer himself surveys. ${ }^{56}$ If the thought is rather that self-interest is somehow straightforwardly rationally justifiable by argument, while direct concern for others is not, this has been disputed by philosophers like Derek Parfit and Ingmar Persson who have pointed out the many puzzles that face the philosopher attempting to argue for the rationality of self-interest. (There appear to be just as many paradoxes and difficulties that face the defender of "purely rational" self-interest as face the philosopher (like Kant) who thinks altruism can be given a straightforward foundation of pure reason. $)^{57}$ Finally, while self-interested concern is of course much more pervasive than otherdirected concern, surely that alone isn't a sufficient reason for counting it as rational while denying that status to less self-interested judgments. ${ }^{58}$ Given these considerations, we do best to reject as unfounded Lehrer's blanket remarks characterizing moral judgments as not rational.

In sum, we haven't found any compelling reasons for either denying emotion a considerable role in reasoning, nor (contra Lehrer's discussion) for discounting moral thought simply because it involves emotion. ${ }^{59}$ On the contrary, we have seen instead that there are substantial philosophical and

\footnotetext{
${ }^{55}$ In correspondence, Lehrer has clarified his position and acknowledged that (despite appearances in How We Decide) he did not, in the end, intend to deny moral judgment a potentially rational status similar to selfinterested judgment. Since many others deny such a parity, however, I consider possible defenses of an asymmetry here.

${ }^{56}$ Lehrer discusses our innate capacities for sympathy and other moral emotions on pp.180-195. See also Appiah's discussion of empirical research into the foundations of compassion (2008, pp.129-136).

${ }^{57}$ Cf. Parfit (1986) and Ingmar (2005).

${ }^{58}$ Lehrer could respond that his defense of the non-rationality of moral judgments is not based simply on their emotional basis but also the evidence that often people will, when pressed, confabulate justifications (i.e. give post-hoc rationalizations) for many moral judgments. (Lehrer discusses the social psychologist Jonathan Haidt's research on this topic briefly on p.174). There are several difficulties with this sort of argument, but here I'll just suggest one: ask the man on the street what justifies his egoistic self-concern (over, say, an equal concern for others). The hasty and flimsy justifications which will flow forth also seem to amount to a form of confabulation (in the sense Lehrer, following Haidt, uses that term), yet I doubt Lehrer would want to conclude that such self-interested concern is thus not rational. (Haidt also offers other arguments that are taken to undermine the objectivity of a large class of moral judgments. For criticisms of those arguments, see Liao (forthcoming).

${ }^{59}$ A persuasive argument which goes significantly further and concludes that often emotion is required for the full understanding of an event (and thus necessary for virtue) can be found in Starkey (2008).
} 
empirical resources for giving emotion an appropriate place in a properly expansive conception of rationality. ${ }^{60}$

None of this is to say that there aren't many situations in which emotions can distort our moral (or other) reasoning; such distortion is sadly all too easy to find, and it is a real threat. ${ }^{61}$ It is rather to point out that adequately distinguishing such cases of illegitimate influence from apt modes of thought is clearly going to require a criterion that makes reference to more that the mere fact that emotions are involved. (As Gaita nicely puts it: "a dispassionate judgment is not one which is uninformed by feeling, but one which is undistorted by feeling." ${ }^{\prime 62}$ ) Accordingly, we need not feel pressured by critics of $A H X$ to discount the rationality of Derek's conversion solely in virtue of its basis in emotive experiences.

Further, this conclusion regarding the compatibility of emotion and reason is one that plainly has relevance for my earlier consideration of the ability of $A H X$ (and other films) to influence viewers by engaging emotions. Given the elementary and necessary connection between the emotions and our capacity to reason about how to live, it seems rash to assume that films that sway us emotionally are thus automatically rationally suspect. ${ }^{63}$

This isn't to claim (improbably) that there can't be works of art which traffic in a morally problematic kind of emotional manipulation. Rather, as before, it is to point out that such works need to be distinguished along lines other than the mere recognition that the works engage our emotions. ${ }^{64}$ How, then, can we distinguish those art works that reasonably move us from those that irresponsibly manipulate? One attractive approach is Carroll's suggestion that the lines be drawn epistemically:

Thus, it is not the case that all mass art representations threaten reason; only those that encourage defective cognitive states, like false beliefs or inaccurate patterns of attention, are affronts to reason- and not because they are emotional states, but only because they are epistemologically defective. ${ }^{65}$

On this account, despite sharing emotionally forceful cinematic techniques, a film like American History $X$ is relevantly distinct from Triumph of the Will because of key epistemic differences: the former aims at bringing forth true

\footnotetext{
${ }^{60}$ Alice Crary's argument for "wide rationality" is one recent and notable attempt with which I am in sympathy. Cf. Crary (2007) See also the essays on morality in Diamond (1991). Arpaly (2003, p.62) helpfully points out that such an expansive conception of reason can be perfectly compatible with many common and plausible theses about rationality (e.g. a requirement of coherence, a sensitivity to evidence, and an ability to be motivated by reasons to a degree proportional to their force as reasons).

${ }^{61}$ In $A H X$ it is suggested that Derek's racist impulses have resulted in large part from his father's powerful (and distorting) emotional influence over his son, just as Danny's racism seems derived largely from the emotional need to mimic both his father and older brother (who becomes a father figure after their father's death). (Thanks to Murray Smith for emphasizing this point.)

${ }^{62}$ Cf. Gaita (1998, p.89)

${ }^{63}$ Not surprisingly, emotional responses turn out to be invaluable in narrative art for reasons similar to why they are fundamental in rational decision-making (i.e. they provide markers of valence and manage our attention.) Cf. Carroll (1998, p.269): "Attention management is the central function of the emotions with respect to fiction."

${ }^{64}$ Cf. Robinson (2005, p.134): "Dispassion in the sense of lack of passion is simply inappropriate; a passionless encounter with a work of art, far from being the proper aesthetic way to proceed, may in fact prevent us from understanding it at all.'

${ }^{65}$ Carroll (1998, p. 257) Also Cf. Nussbaum (1995)
} 
beliefs and accurate perceptions, while the latter fosters lies and distortions. ${ }^{66}$ (In $A H X$ we are skillfully persuaded to emotionally engage with a morally problematic protagonist, but this engagement leads to a demonstration of the falsity of his ideology that is more powerful than an "unemotional" treatise on the wrongness of racism could ever hope to be.) Admittedly, much more would need to be said to adequately defend and flesh out this suggestion of an epistemic criterion - my goal here just to make note of this plausible and promising route of investigation. ${ }^{67}$ More generally, my goal in this brief discussion of reason and emotion has been to emphasize that the acceptance of a Platonic pessimism regarding emotion's ability to reasonably persuade (whether in daily life, or while at the movies) is, given the evidence, far from mandatory.

\section{Conclusion}

With the help of a variety of philosophical resources, I've argued that several aspects of American History $X$ that have been criticized as flaws (e.g., the idealization of the protagonist, the manner in which his conversion is depicted, and the suggestion by the film that such a conversion allows for a better life) are best recognized as assets. The characterization of Derek in fact allows for a particularly gripping narrative arc, his conversion is realistically presented as a gradual and emotional process, and his eventual change of heart is plausibly put forward as both a psychological and ethical advance.

In addition, we've seen that there are good reasons to be wary of a classic but misguided conception of the mind in which emotions are said to be fundamentally at odds with rationality. The same reasons that ground that wariness also help support a conception of art in which works that engage the emotions are not thereby necessarily suspect. These considerations allow for further defense of the film. Short of an independent argument that Derek's experiences in prison somehow resulted in him falling into irrationality in abandoning his racism, we can defend his conversion as legitimate even though emotions played a key role in its facilitation. Also, short of an argument that the particular cinematic techniques employed in $A H X$ lead viewers into adopting false beliefs or otherwise faulty cognitive states, we can conclude that our initial worry about this film's not insignificant ability to persuade viewers through the engagement of emotions need not be seen as a barrier to endorsing American History $X$ as a legitimately stirring and moral work.

Acknowledgments: I'd like to thank my colleagues Todd May, Charles Starkey, and Allen Thompson for helpful discussions of these issues. I'd also like to thank Sean Allen-Hermanson, Carlene Bauer, Angela Curran, Troy Jollimore, Spencer Lamm, Joseph Mai, Michael McKenna, Murray Smith, Aaron Smuts,

\footnotetext{
${ }^{66}$ Note that this is a significant refinement of the approach I briefly mention in section 3 (by which a work is legitimate if it has a "noble end.") Carroll's suggestion allows us to criticize a work for inculcating false beliefs and epistemologically unjustified patterns of reasoning even if those beliefs and patterns are put in the service of a morally admirable end. (A moral end may not justify an epistemically problematic means.) Note also that a film may foster defective epistemic states in the viewer in a wide variety of ways: the illegitimate manipulation of emotion is just one way to mislead.

${ }^{67}$ Carroll does spell out this idea at greater length in his later, related discussion of "ideology." (pp. 374-388.)
} 
and Susan Watson for insightful comments on earlier drafts of this essay. In addition, thanks to Jonah Lehrer for helpful correspondence.

\section{Bibliography}

Appiah, Kwame Anthony. (2008) Experiments in Ethics. Cambridge: Harvard University Press.

Arpaly, Nomy. (2003) Unprincipled Virtue: An Inquiry into Moral Agency. New York: Oxford University Press.

Blum, Lawrence. (forthcoming) "False Racial Symmetries in Far from Heaven and Elsewhere" in Understanding Love through Philosophy, Film, and Fiction, eds. Susan Wolf \& Christopher Grau. New York: Oxford University Press.

Carroll, Noël. (1990) The Philosophy of Horror or Paradoxes of the Heart. New York: Routledge

Carroll, Noël. (1998) A Philosophy of Mass Art. Oxford: Clarendon Press

Carroll, Noël. (2008) The Philosophy of Motion Pictures. Oxford: Blackwell Publishing.

Churchland, Patricia Smith. (1998) "Feeling Reasons" in On the Contrary: Critical Essays, 1987-1997, eds. Paul M. Churchland and Patricia Smith Churchland. Cambridge: MIT Press.

Coplan, Amy. (2004) "Empathic Engagement with Narrative Fictions," The Journal of Aesthetics and Art Criticism, 62 (2), 141-152.

Crary, Alice. (2007) Beyond Moral Judgment. Cambridge: Harvard University Press.

Damasio, Antonio R. (1995) Descartes' Error: Emotion, Reason, and the Human Brain. New York: Harper Perennial.

Devereaux, Mary. (1998) "Beauty and Evil: the case of Leni Riefenstahl's Triumph of the Will" in Aesthetic and Ethics: Essays at the Intersection. ed. Jerrold Levinson New York: Cambridge University Press.

Diamond, Cora. (1991) The Realistic Spirit: Wittgenstein, Philosophy, and the Mind. Cambridge: MIT Press.

Flory, Dan. (2008) "Spike Lee and the Sympathetic Racist" in Philosophy, Black Film, Film Noir. University Park: The Pennsylvania State University Press.

Gaita, Raimond. (1998) A Common Humanity: Thinking About Love and Truth and Justice. London: Routledge. 
Gaut, Berys. (1999) "Identification and Emotion in Narrative Film" in Passionate Views: Film, Cognition, and Emotion, eds. Carl Plantinga and Greg M. Smith. Baltimore: The Johns Hopkins University Press.

Jollimore, Troy \& Barrios, Sharon (2004) "Beauty, Evil, and The English Patient" Philosophy and Literature, 28:23-40.

Kupfer, Joseph. (1999) "Virtue and Happiness in Groundhog Day" in Visions of Virtue in Popular Film. Westview Press.

Lehrer, Jonah. (2009) How We Decide. Boston: Houghton Mifflin Harcourt.

Liao, S. Matthew (forthcoming) "Bias and Reasoning: Haidt's Theory of Moral Judgment" in New Waves in Ethics, ed. Thom Brooks. Basingstoke: Palgrave Macmillan.

Nussbaum, Martha. (1990) Love's Knowledge: Essays on Philosophy and Literature. New York: Oxford University Press.

Nussbaum, Martha. (1995) Poetic Justice: The Literary Imagination and Public Life. Boston: Beacon Press.

Nussbaum, Martha. (2001) Upheavals of Thought: The Intelligence of Emotions. Cambridge: Cambridge University Press.

Parfit, Derek. (1986) Reasons and Persons. New York: Oxford University Press.

Perkins, Victor. (1993) Film As Film: Understanding and Judging Movies. Da Capo Press.

Persson, Ingmar. (2005) The Retreat of Reason: A Dilemma in the Philosophy of Life. Oxford: Oxford University Press.

Robinson, Jenefer. (2005) Deeper than Reason: Emotion and its Role in Literature, Music, and Art. Oxford: Clarendon Press.

Rollyson, Carl. (2009) “"Fascinating Fascism' Revisited: An Exercise in Biographical Criticism," Journal of Historical Biography 5 (Spring 2009): 122, http://www.ufv.ca/jhb

Smith, Murray. (1995) Engaging Characters: Fiction, Emotion, and the Cinema. Oxford: Clarendon Press.

Smith, Murray. (1999) "Gangsters, Cannibals, Aesthetes, or Apparently Perverse Allegiances" in Passionate Views: Film, Cognition, and Emotion, eds. Carl Plantinga and Greg M. Smith. Baltimore: The Johns Hopkins University Press. 
Smith, Paul. (2007) "American History X" in America First: Naming the Nation in US Film, ed. Mandy Merck. Abingdon: Routledge.

Sontag, Susan. (1975) "Fascinating Fascism," New York Review of Books, 22 (1), February 6, 1975. http://www.nybooks.com/articles/9280

Starkey, Charles. (2008) "Emotion and Full Understanding" Ethical Theory and Moral Practice 11 (4). 